\title{
Ülo Ennuste: Towards Special Methodological Problems of Macro-Optimal Sociocybernetic International Economic Sanctioning Coordination Modelling: Introductory Remarks on Preliminary Postulates and Conjectures
}

the reason sanctions are popular is not that they are known to be effective, but "that there is nothing else between words and military action if you want to bring pressure upon a government"

Jeremy Greenstock

\section{Introductory remarks}

In economic literature, one of the first examples of economic international sanctions is provided by the measures taken by the U.K. government in the Rhodesia independence conflict (Bannock et al., 1978, p. 174).

As we can see also in current publications in recent Wikipedia definitions,

Economic sanctions are domestic penalties applied by one country (or a group of countries) on another country (or a group of countries). Economic sanctions may include various forms of trade barriers and restrictions on financial transactions. Economic sanctions are not necessarily imposed because of economic circumstances-they may also be imposed for a variety of political and social issues. Economic sanctions can be used for achieving domestic political gain. (Wikipedia, n.d.)

Actually, the most recent example for the EU-28 is provided by the third round of measures presently implemented in unison as partners by the EU and the USA in the camp against the Russian Federation in the case of the Russian aggression in South-East Ukraine (EU, 2014).

While this sanctioning seems to develop as a many-stage process (the preparation of the next round was announced by the European Council on 30 August 2014, and on 12 September all this was published in the Bulletin of European Union (EC, 2014), there may be still time to analyze the structure of the sanctioning 
process mechanism design in an economic union with sovereign national member states - theoretically in the spectre of modern stochastic coordinated game theoretical and institutional economic, etc. methods (Appendix A), and make corrective suggestions.

\section{Modelling remarks}

Theoretically, the most complicated problem in the planning of collective sanctions in the EU context in this third round is the central optimal coordination of the defensive/deterrent economic sanction measures taken by the imposing EU Member States, as these penalty measures, projected by the imposing countries against transgressing third national economy, are as a rule hurting the Member States' economies as well-and-directly and indirectly to different stochastic degrees.

First of all, via counter-attacks by the transgressor in many ways: political, economic, military etc. (at least in this conflict, see The Economist, 2014).

Thus from the cybereconomics perspective, the adequate optimization criterion has to be complex: for example, real economic risk axis, and complementary imaginary political risk axis. Additionally, complications in this model may come into game via third-country fuzzy logic and dictators' infamous moral hazards. And most importantly - the complexity of the problems increases as, alongside sanctions to the antagonist, the coalition union has to introduce complementary domestic economic policies and mechanisms for the minimization of losses inflicted to the national member economies from the counter-reactions of the antagonist, and mechanisms for truth-telling in the coalition.

Alas, in the text about the EU sanctions (EU, 2014), we openly cannot find a smallest measure by the EU to organize complementary domestic counterstrategic coordination mechanisms, institutions, crisis committees, etc. It seems that these complex circumstances make hardly a pragmatic normative coordination quantitative modelling too bad (see, e.g., Schlefer, 2012) but at least it may clarify the lines of reasoning - for example, why in this kind of complex uncertainties a MinMax expected loss criteria may be the most adequate; how complex plane optimization may provide an opportunity to measure the angels/slopes between alternative vector-risk criterion (economic and political) strategies; and the missing point that the implementation of international economic sanctions has to be prepared beforehand domestically, especially in energy security, etc. 
The basic existing modern evolutionary heterodox macro-socio-economics and -cybernetics - even though there are missing financial theories and international trade theories by Krugman, and others - provides for this special example at least a three-postulate pillar, which is probably a sufficient methodological framework for modelling about an optimal coordination of international sanctions for the group of countries under the condition of complex uncertainties:

1) The consideration of uncertainties and risks in the hierarchical coordinationand these in the most complicated stochastic cases such as, for example, Donald Rumsfeld's "known unknowns", Bayesian, etc. (on the examples see Ennuste, 1989) mixed strategies and scenario approaches in the many stages of game theoretic decentralized/democratic coordinated equilibrium mechanisms.

2) The modelling of coordinated optimization of socio-economic institutional/ mechanism structural changes and designs (Ennuste, 2003).

3) The consideration of changes in national knowledge structures and consideration connected with communication moral-hazard risks and moral coordination (Ennuste, 2008).

All the various contributions of these methodological tools to the implementation by the agents of optimal strategies and institutional designs in terms of antagonistic coordinated games are presented in the above-quoted papers by the author, containing also relevant significant classical source references.

\section{Preliminary conjectures}

Firstly, in the case of financial-economic union, the optimal sanctioning of the third national economy, the specific all-union sanctioning tax for the Member States (as in the ESM example) should be introduced for solidarity compensation mechanism (analogous to, e.g., the ESM mechanism, the European Semester mechanism, etc.) of the union's members who suffer the worst losses in the economic sanction war-the war in defence against the escalation of political and armed aggression.

Secondly, besides other common real factors such as international trade losses in the sanction wars, also financial and capital losses should be taken into consideration, as well as losses/gains in the imaginary international credibility capitals of national societies and losses in the respectability of their political and knowledge structures. 
Thirdly, and most importantly, strict material and moral penalties and restrictions should be imposed on the institutions/agents who internationally distort national knowledge structures, authorized under the auspices of the third transgression state, whether they are resident agents or not - as such distortions prolong the duration of economic wars with relevant damages to the probabilities of national sustainability (Ennuste, 2008).

Complex modelling involving indirect relations and feedbacks may lead to counter-intuitive conclusions. For example, from the aspect of impairment of Russia's economy, the Mistral deal may be, with great probability, justifiedand in the example of Estonia, financial restrictions on some Russian capitalfounded banks may probably give new opportunities to improve the national balance of payments and international investment position, or a good innovation in the borderline science parks to develop Russian camps, etc.

For the qualitative measurement of effectiveness of the implied sanctions in the short term:

1) The speed of national statistical production should be enhanced on the level of present ICT level.

2) The official national statistical publications have to be made more transparent and comprehensive, and available to the public. For example, Estonian Statistical Yearbooks do not contain estimations of the assets of households (because administrators here are regularly disregarding the difference between income and wealth/capital (see, e.g., Piketty, 2014). This, for example, makes a quick assessment of national households' property losses by cuts in gas supply by the transgressor cumbersome (see Appendix B).

3) Especially national central banks must openly publish international balances of payments also in the country by country format, etc. Considering complex uncertainties (e.g., fuzzy logic of the antagonistic country), it is important to bear in mind the effectiveness assessments that in these conditions the diversity of sanctions is as important as the generally moderate degrees of sanctions - and open possibilities for further bargains.

Last but not least, a key part of the answer to how to minimize maximum losses for the imposing cooperative camp is to prepare favourable national real and information environments in advance. To make beforehand the necessary adjustment processes in foreign trade and foreign financial sectors, first of all concurrent investments are needed. But also investments in national information 
cyber-security and national statistical speed and credibility and sufficient completeness fields and, which is perhaps the most cumbersome, favourable preparation in national knowledge and political structures for adequate cooperative coordination.

\section{References}

Applebaum, A. (2014), 'War in Europe is not a hysterical idea,' The Washington Post, 29 August 2014. Retrieved from http://www.washingtonpost. com/opinions/anne-applebaum-war-in-europe-is-not-a-hystericalidea/2014/08/29/815f29d4-2f93-11e4-bb9b-997ae96fad33_story.html [accessed Aug 2014]

Bannock, G.; Baxter, R. E. \& Rees, R., eds. (1978) The Penguin Dictionary of Economics, $2^{\text {nd }}$ ed., Harmondsworth: Penguin.

Ennuste, Ü. (1989), 'Some Models of Stochastic Planning Mechanisms,' Finnish Economic Papers, vol. 2. Retrieved from http://econpapers.repec. org/article/fepjournl/v_3a2_3ay_3a 1989_3ai_3a2_3ap_3a116-124.htm [accessed Aug 2014] (2003), A Linear Planning Analysis of Institutional Structure in the Economy, Policy Documentation Center. Retrieved from http://pdc.ceu. hu/archive/00001564/01/linear.PDF [accessed Aug 2014]

(2008), 'Synthetic conceptions of implementing mechanisms design for public socio-economic information structure: illustrative Estonian examples,' in Socio-Economic and Institutional Environment: Harmonisation in the EU Countries of Baltic Sea Rim, vol. 4, pp. 9-39. Retrieved from http://www.ies. ee/iesp/No4/Ennuste.pdf [accessed Aug 2014]

EC (2014), 'Council Implementing Regulation (EU) No 961/2014 of 8 September 2014 implementing Regulation (EU) No 269/2014 concerning restrictive measures in respect of actions undermining or threatening the territorial integrity, sovereignty and independence of Ukraine,' L271, Official Journal of the EU, 12 September 2014.

EU (2014), 'EU Sanctions against Russia over Ukraine crisis,' European Union Newsroom Highlights. Retrieved from http://europa.eu/newsroom/ highlights/special-coverage/eu_sanctions/index_en.htm [accessed Aug 2014]

Kasparov, G. (2014), “It's a War, Stupid!” Times, 30 August 2014. Retrieved from http://time.com/3227869/garry-kasparov-its-a-war-stupid/ [accessed Aug 2014] 
Kukk, K. (2005), The White Book: Losses Inflicted on the Estonian Nation by Occupation Regimes 1940-1991, State Committee on the Investigation into Repression Policy of Occupation, Tallinn: Estonian Encyclopaedia Publishers. Retrieved from http://digar.nlib.ee/digar/show/?id=8192 [accessed Aug 2014]

Piketty, T. (2014), Capital in the Twenty-First Century, London: Belknap Press of Harvard University Press.

Schlefer, J. (2012), The Assumptions Economists Make, Cambridge, MA: Harvard University Press.

The Economist (2014), 'The war in Ukraine: reversal of fortune,' The Economist Briefing, 6-12 September 2014, vol. 412, no. 8903, pp. 21-24.

Wikipedia (n.d.), 'Economic Sanctions.' Retrieved from http://en.wikipedia.org/ wiki/Economic_sanctions [accessed Aug 2014] 


\section{APPENDIX A. Technical remarks: the institutional mechanism structure of the players}

\begin{tabular}{|l|c|c|c|c|}
\hline $\begin{array}{l}\text { Sanctioning Alliance } \\
\text { Coordination } \\
\text { Symposium*(SCS) }\end{array}$ & $\begin{array}{c}\text { Transgres- } \\
\text { sor/ Antago- } \\
\text { nist Third } \\
\text { Country }\end{array}$ & $\begin{array}{c}\text { Significant } \\
\text { Fourth } \\
\text { Countries }\end{array}$ & $\begin{array}{c}\text { Known } \\
\text { unknowns }\end{array}$ & $\begin{array}{c}\text { Unknown } \\
\text { knowns } \\
\text { and } \\
\text { unknowns }\end{array}$ \\
\hline EU US & RF & $\begin{array}{c}\text { CH BRICS, } \\
\text { etc. }\end{array}$ & $\begin{array}{c}\text { Natural ab- } \\
\text { normalities } \\
\text { like Iceland } \\
\text { volcanic } \\
\text { eruptions, } \\
\text { etc. }\end{array}$ & $\ldots \ldots . . . . .$. \\
\hline $\begin{array}{l}\text { Symposium of 28 } \\
\text { Member States (SEU) }\end{array}$ & $\begin{array}{c}\text { Non- } \\
\text { coordinated } \\
\text { antagonist }\end{array}$ & $\begin{array}{c}\text { Non-coor- } \\
\text { dinated }\end{array}$ & & \\
\hline $\begin{array}{l}\text { Member States' } \\
\text { Coordinative } \\
\text { Symposiums (MCS), } \\
\text { e.g.: EEMCS, etc. }\end{array}$ & & & & \\
\hline
\end{tabular}

* Symposium - a code name for the coordinative mechanisms/institutions implementing material and moral side-payments (Ennuste, 2008).

The risk-game theoretical coordinated decomposed equilibrium solution is based on the optimal mechanisms optimizing the coalition members' losses considering economic and political losses risks: a) self-inflicted directly by sanction strategies (e.g., curtailing imports from the adversary); b) losses/gains inflicted directly by side-payments (material and moral) in the situation of optimal all-coalition collective sanction strategies; c) loss risks indirectly by counter-attacks; d) significant economic losses may be in the national (domestic and in the other countries) capital (private and households), GDP real genuine volume, actual individual consumption, etc., in economic potential and probable sustainability, in labour force, etc.; the moral risk-losses may be the members' international political and economic and military credibility ratings, etc. 


\section{APPENDIX B. Illustrative empirical case study remarks on Estonian example}

\section{Conjecturable macro-economic hypotheses of Estonia's national losses and damages connected with Russian aggression in 2014-2015(?) and with the EU sanctions}

Sanctions are still an important tool [...] Only sanctions that bring the costs of Putin's war home can have an impact now.

(Kasparov, 2014)

H.1.: Russia's military territorial aggression in East Ukraine will be liquidated mainly by Ukraine's military activities and by the complementary US and EU collective sanctions plus material aid, or S+ (Appelbaum, 2014). Russia's military territorial aggression or occupation of the Baltic States will not necessarily follow due to the quoted $\mathrm{S}+$ as the necessary factor.

P.S.: Economic estimates of Estonia's national losses during the Russian occupation in 1940-1991 reached ca 1(+/-0.5) trillion kroons (Kukk, 2005, pp. 141-174), which is about 30 times the current Estonian net national income (NNI). This means that if the $\mathrm{S}+$ can reduce the risks of occupation a couple of percentage points, the expected national gain, in terms of economy, may reach up to 40 to 60 bn euros (estimated by means of analogy with the 1940-1991 occupation).

H.2.: In case Russian military intervention against the Baltic States will be prevented, Estonia's national sub-regional loss risks connected with RussiaUkraine War in 2014-2015(?) may be estimated by the following main big-risk components:

a) Russia's direct retaliatory counter-sanctions against Estonia as an EU Member State: inflicting losses to the volume of $\Delta$ NNI (e.g., via bilateral trade. My present preliminary conjecturable estimate of this potential risk may be in the volume of 0.4 bn euros p.a. (here 0.4 denotes an approximate standard numeral $0.4+/-0.5$ ), including losses of complete cut-off from Russian gas supply, which is presently the single gas supply for the Baltic States); plus damages to Estonian Domestic Assets- $\triangle$ DA (e.g., complete gas cuts may present potential risk to nullify completely the value of the entire Estonian national gas system infrastructure. The damage to the domestic capital may be several billions plus investments to ground replacement infrastructure, etc.) 
b) Estonia's possible losses inflicted by the EU's collective sanctions against Russia, implemented in trade and financial/banking and travel sectors (amounting almost certainly to $0.2-0.4$ bn euros, and probably, at least partially, are included in compensations by the European Commission)

c) Possible damages to the international credibility of Estonian business and investment climate and sustainability - and political security risks stemming from the intensification of ethnic conflicts and stirring up irredentist fifth columns ("little green men") in the Estonian ample Russian-speaking enclaves as in April 2007 in Tallinn, etc. And last but not least-this sanction war is almost certainly stirring up a propaganda war between the Baltic States and the Kremlin and additional poisoning of national knowledge spaces especially in the Baltic Russian-speaking diasporas (even though Baltic national knowledge structure mechanisms are not yet on the level of the Kremlin's think-tanks' dialectical fuzziness). Additional development/sustainability losses, at least for Estonia, are almost certainly on the horizon.

P.S.: It probably seems too early to summarize quantitatively and, eventually, economically provisional estimates about Estonia's expected possible national losses and damages risks, which are connected with the EU collective sanctions against the Russian Federation. However, without any doubt these are magnitudes smaller as maybe rationally expected without these notorious sanctions.

Prof. Ülo Ennuste, D.Sc. has successfully worked at the Tallinn Institute of Economics of the Estonian Academy of Sciences, at the Tallinn Technical University, and at the International University Audentes. Since 2008, Ülo Ennuste has been honorary doctor in the field of international economics at the International University Audentes, and member of the editorial board of the Baltic Journal of European Studies (the former Proceedings of the Institute for European Studies). His main fields of interests are in the theory of economic systems and planning under incomplete information. 